\title{
Relationship between low-cloud presence and the amount of overlying aerosols
}

\author{
Chul Eddy Chung ${ }^{1}$, Anna Lewinschal ${ }^{2}$, and Eric Wilcox ${ }^{1}$ \\ ${ }^{1}$ Division of Atmospheric Sciences, Desert Research Institute, Reno, NV 89512, USA \\ ${ }^{2}$ Department of Meteorology and Bolin Centre for Climate Research, Stockholm University, 10691 Stockholm, Sweden \\ Correspondence to: Chul Eddy Chung (eddy.chung@dri.edu)
}

Received: 9 February 2016 - Published in Atmos. Chem. Phys. Discuss.: 12 February 2016

Revised: 20 April 2016 - Accepted: 26 April 2016 - Published: 11 May 2016

\begin{abstract}
Aerosols are often advected above cloud decks, and the amount of aerosols over cloud has been assumed to be similar to that at the same heights in nearby clear sky. In this assumption, cloud and aerosol above cloud-top height are considered randomly located with respect to each other. The Cloud-Aerosol Lidar and Infrared Pathfinder Satellite Observations (CALIPSO) data are analyzed here to investigate this assumption on global scales.

The CALIPSO data reveal that the aerosol optical depth (AOD) above low cloud tends to be smaller than in nearby clear sky during the daytime, and the opposite is true during the nighttime. In particular, over oceanic regions with widespread low cloud, such as the tropical southeastern Atlantic Ocean and northeastern Pacific Ocean, the daytime AOD above low cloud is often $40 \%$ smaller than in surrounding clear skies.
\end{abstract}

\section{Introduction}

The magnitude of the global aerosol direct radiative forcing (due to absorption and scattering of incoming sunlight) has been estimated to range from -0.85 to $0.15 \mathrm{~W} \mathrm{~m}^{-2}$ in the 5 th Intergovernmental Panel on Climate Change report (Myhre et al., 2013a). This uncertainty range is based partly on aerosol simulations (Myhre et al., 2013b) and also on semiempirical studies (e.g., Myhre, 2009; Su et al., 2013) where aerosol observations were used to constrain the aerosol simulations.

A part of this uncertainty range stems from uncertainties related to the vertical distribution of aerosols. Radiation modeling studies (Haywood and Shine, 1997; Meloni et al., 2005; Choi and Chung, 2014) showed that the sensitivity of aerosol forcing to the aerosol vertical profile arises mainly as a consequence of the location of absorbing particles relative to clouds. Absorbing aerosols above clouds absorb both downwelling solar radiation and upwelling radiation reflected from the underlying clouds, giving stronger absorption and more positive forcing than in the absence of clouds or if the aerosol is located below cloud. Thus, it is important to determine as accurately as possible the amount of absorbing aerosols above clouds. This also means that cloud amount and albedo become important factors in determining the forcing of absorbing aerosols. Chand et al. (2009) found that, for biomass burning smoke (with a single-scattering albedo, SSA, of 0.85) over the southeastern Atlantic stratocumulus clouds, the net radiative forcing changes the sign from negative to positive when the cloud fraction exceeds $40 \%$.

When global aerosol simulations were constrained by clear-sky aerosol optical depth (AOD) derived from MODderate Resolution Imaging Spectroradiometer (MODIS) to reduce the uncertainty in aerosol radiative forcing estimates (e.g., Chung et al., 2005; Myhre, 2009; Su et al., 2013), the AOD was assumed to be homogeneously distributed within a grid cell. Clouds, on the other hand, do not necessarily occupy the entire grid cell, and are prescribed over a portion of the grid cell. This procedure thereby assumes that the AOD is independent of clouds and that the AOD above clouds is the same as that at the same height in the clear-sky neighborhoods within the grid cell. The main goal of the present study is to validate this assumption with observations. As mentioned above, the radiative forcing of absorbing aerosols is enhanced above bright surfaces such as clouds. Thus, if absorbing aerosols are actually less or more abundant above 
clouds compared to the clear sky, prescribing a horizontally uniform clear-sky AOD over the entire grid cell would lead to an over- or underestimation of the aerosol direct radiative forcing.

Looking into the amount of absorbing aerosol above cloud has additional scientific significance. Absorbing aerosols above clouds can introduce biases in satellite-retrieved cloud effective radius and optical depth (Haywood et al., 2004). In addition to improving the estimates of aerosol direct radiative forcing, accurate estimates of AOD above clouds and any systematic difference between the AOD above clouds and that in surrounding clear skies could help to improve cloud retrievals from passive satellite sensors.

If aerosols are actually less or more abundant above clouds compared to the clear-sky neighborhoods, what could the possible reasons be? One candidate is large-scale circulation patterns. For instance, advection or emissions of aerosols could be caused by specific circulation patterns or transport of air masses that would also either promote or inhibit lowcloud formation (e.g., Mauger and Norris, 2007). Another candidate is aerosol-cloud interaction. Aerosols were shown to influence underlying cloud by indirect effects and semidirect effects. For example, by analyzing satellite observations, Costantino and Bréon $(2010,2013)$ found that cloud droplet size decreases with aerosol loading when the bottom of an aerosol layer touches the top of the cloud beneath. In contrast, when the aerosol layer is well separated from the underlying cloud, they found no correlation between cloud droplet size and aerosol loading. This indicates that some of the aerosols entrained from cloud top when the aerosol layer touches cloud top become activated as cloud condensation nuclei $(\mathrm{CCN})$ and increase the cloud droplet number concentration and decrease the cloud droplet size. In addition to this indirect effect mechanism, overlying aerosols, in the case of sunlight-absorbing aerosols, can create semi-direct effects by the shortwave radiative aerosol heating. This heating can increase the temperature inversion above the boundary layer, which helps to inhabit the entrainment of freetropospheric dry air through cloud top and thereby produces a moister boundary layer and thus thicker, more reflective clouds (Johnson et al., 2004; Wilcox, 2010). This temperature inversion is enhanced by the fact that atmospheric solar heating by an aerosol layer increases when the layer resides above cloud. These aforementioned aerosol-cloud interactions and possibly more are expected to somehow affect the aerosol amount over cloud by, for example, influencing aerosol deposition.

The Cloud-Aerosol Lidar and Infrared Pathfinder Satellite Observations (CALIPSO) satellite offers global aerosol and cloud vertical profile observations (Winker et al., 2009). Moreover, the Cloud-Aerosol Lidar with Orthogonal Polarization (CALIOP) instrument onboard CALIPSO retrieves aerosol backscatter from space, both in clear and cloudy skies, and thereby offers an ideal platform for determining aerosol amount above clouds. Devasthale and
Thomas (2011) used CALIPSO data to investigate the occurrence of aerosols above liquid water clouds. In an intercomparison of above-cloud AOD from A-Train satellites sensors, Jethva et al. (2014) found that the CALIPSO-derived above-cloud AOD was consistently lower than those derived from the other satellites sensors in the A-Train. Chand et al. (2008) and Liu et al. (2015) both used alternative retrieval methods to the standard CALIPSO algorithm to derive AOD above clouds specifically. Other efforts to quantify abovecloud AOD from passive satellite sensors include the works by e.g., Knobelspiesse et al. (2011), Meyer et al. (2013), Torres et al. (2012), and Waquet et al. (2009, 2013).

Here, we use CALIPSO data and compare the observed AOD above low clouds with that at the same height in the nearby clear sky in order to validate the aforementioned assumption that aerosols and clouds are randomly distributed. If aerosols and clouds are randomly located, the above-cloud AOD would be equal to that in clear sky at the same height. In other words, if the aerosol distribution is independent of the presence of clouds, the AOD at any altitude should be the same whether it is measured in clear sky or cloudy sky. If the aerosol distribution covaries with that of clouds, either through the semi-direct effects or large-scale atmospheric circulation, systematic differences between the AOD above clouds and that in clear sky should be visible. Here, we utilize CALIPSO observations to investigate the AOD above cloudtop height in relation to the presence of clouds on a global scale. We calculate $532 \mathrm{~nm}$ AOD above cloud-top height, and this AOD differs from the AOD above cloud retrieved by the CALIOP operational algorithm. Furthermore, we compare the AOD above low-cloud-top height with that at the same height in the nearby clear sky, and this comparison is not possible with data retrieved by passive sensors even though passive sensors could provide the AOD above cloud. Thus, the use of CALIPSO retrievals is necessary for our investigation. The focus is solely on AOD above cloud-top height, and thus aerosol indirect effects on cloud microphysics are not addressed in the present study.

The layout of the study is as follows. The CALIPSO data and retrieval algorithms relevant for the present work are described in Sect. 2. Section 3 describes the method used to derive the global above cloud AOD from CALIPSO standard data products. The results are presented in Sect. 4, followed by a discussion and conclusions in Sect. 5 .

\section{Data}

The CALIPSO satellite was launched in April 2006 as a part of the A-Train satellite constellation and has been collecting atmospheric data since June 2006. The satellite has a 16-day repeat cycle and collects global data between $82^{\circ} \mathrm{N}$ and $82^{\circ} \mathrm{S}$. The CALIOP instrument onboard the CALIPSO satellite is a near-nadir viewing lidar that collects vertical profiles of atmospheric backscatter data. The lidar instru- 
ment transmits polarized light at the wavelengths 532 and $1064 \mathrm{~nm}$ and measures the range-resolved backscatter intensity for these wavelengths, including the amount of depolarization (i.e., backscatter signal polarized perpendicular to the outgoing beam) at $532 \mathrm{~nm}$. CALIPSO level 1 data consist of calibrated attenuated backscatter data at a resolution of $1 / 3 \mathrm{~km}$ in the horizontal direction along the ground track and $30 \mathrm{~m}$ in the vertical below $8.2 \mathrm{~km}$. Atmospheric features, such as clouds and aerosols, can be identified in the backscatter data based on their enhanced backscatter intensity compared to the background molecular backscatter from a clear atmosphere. An overview of the CALIPSO mission can be found in the work by Winker et al. (2009).

CALIPSO level 2 data are derived with a collection of algorithms that identify and classify atmospheric feature layers and calculate their atmospheric extinction. Detailed descriptions of the CALIPSO data acquisition and processing are provided by $\mathrm{Hu}$ et al. (2009), Liu et al. (2009), Omar et al. (2009), Vaughan et al. (2009), and Young and Vaughan (2009). The layer detection algorithm uses an iterative, multi-scale approach when searching for cloud and aerosol layers in the backscatter data (Vaughan et al., 2009). The algorithm is designed to retain as much as possible of the horizontal inhomogeneities in the backscatter data, while performing a minimum of horizontal averaging to increase the signal-to-noise Ratio $(S / N)$, so that the backscatter of a feature, if present, exceeds the detection threshold. The layer detection algorithm identifies the height of the top and the bottom of the feature layers - i.e., the bounding altitudes of the area where the backscatter signal exceeds that of the background atmosphere. Thus, an altitude-dependent threshold value array for enhanced backscatter has to be determined for each lidar profile. This threshold value array varies with background illumination, which depends on both solar radiation and surface albedo (Winker et al., 2009). During daytime, the background noise is large, which makes detection of tenuous aerosol layers more difficult compared to detection in nighttime retrievals. During daytime, faint aerosol layers can remain undetected, or their geometrical thickness can be underestimated to a larger extent than during nighttime. This may, in turn, lead to an underestimation of the total daytime AOD compared to that derived from nighttime data (Rogers et al., 2014). Moreover, during daytime, reflection of solar radiation from clouds can contribute to the background noise in the lidar profiles, and could, in a similar manner, lead to undetected faint aerosol layers above clouds (Kacenelenbogen et al., 2014).

The layers that are identified by the iterative layer detection algorithm are separated into cloud and aerosol layers based on their backscatter signals in all three channels, as well as their altitude and geographical position (Liu et al., 2009). However, the cloud-aerosol separation algorithm is applied for features detected at a horizontal averaging resolution of $5 \mathrm{~km}$ or lower. All features detected at one single shot are classified as clouds. In regions with large dust emis- sions this can lead to misclassifications of dense dust layers as clouds.

Features identified as aerosols are further categorized according to aerosol type (Omar et al., 2009). The CALIPSO algorithm uses six different characteristic aerosol models to represent atmospheric aerosols: dust, polluted dust, smoke, clean marine, clean continental, and polluted continental. These representative aerosol models include assumptions about the particle size distribution as well as the optical properties of the aerosol. The aerosol extinction coefficients are derived based on the aerosol model and the corresponding representative lidar ratio associated with each aerosol type. Thus, the total aerosol extinction and AOD is dependent on the accuracy of the aerosol model and that the correct aerosol model is chosen for an aerosol layer.

\section{Methodology}

To investigate aerosol abundance above low clouds, we use the CALIPSO level 2 data to calculate the AOD above the maximum low-cloud-top height in each grid cell in clear sky as well as the AOD above low clouds on a global $2^{\circ} \times 5^{\circ}$ latitude-longitude grid. We use version 3.01 of the level 2 data, which covers the time period from June 2006 to October 2011. The daytime and nighttime data are analyzed separately. We focus primarily on daytime data here because aerosol direct radiative forcing is due almost entirely to the absorption and scattering of solar radiation. However, nighttime data which have higher $S / N$ are included for comparison. We study the AOD above low clouds since aerosols are typically advected above low clouds, and the low-cloudtop height provides a more uniform reference altitude than a combination of all clouds.

In this study, the aerosol profile product and cloud layer products are used. The horizontal resolution of the level 2 aerosol profile product is $5 \mathrm{~km}$ along the satellite ground track, while cloud layer products are available at 5 and $1 / 3 \mathrm{~km}$ (corresponding to one single lidar shot) horizontal resolutions. The cloud layer products are utilized to identify and separate $5 \mathrm{~km}$ horizontal resolution clear-sky aerosol extinction profiles from profiles containing low clouds. In the CALIPSO data products, low clouds are defined as clouds with tops below $680 \mathrm{hPa}$ (Liu et al., 2005). The detection ability of the CALIPSO feature detection algorithm is dependent on the spatial averaging of the lidar backscatter data. Tenuous features typically require averaging over a large horizontal distance to be detected, while more opaque layers require less horizontal averaging to be detected. The $5 \mathrm{~km}$ cloud layer product contains all the cloud layers detected by the CALIPSO feature detection algorithm at horizontal averaging resolutions of $5 \mathrm{~km}$ or lower in the iterative feature scanning procedure (see Vaughan et al., 2009, for a detailed description of how atmospheric features are identified). Cloud layers detected at higher horizontal resolution (at one 


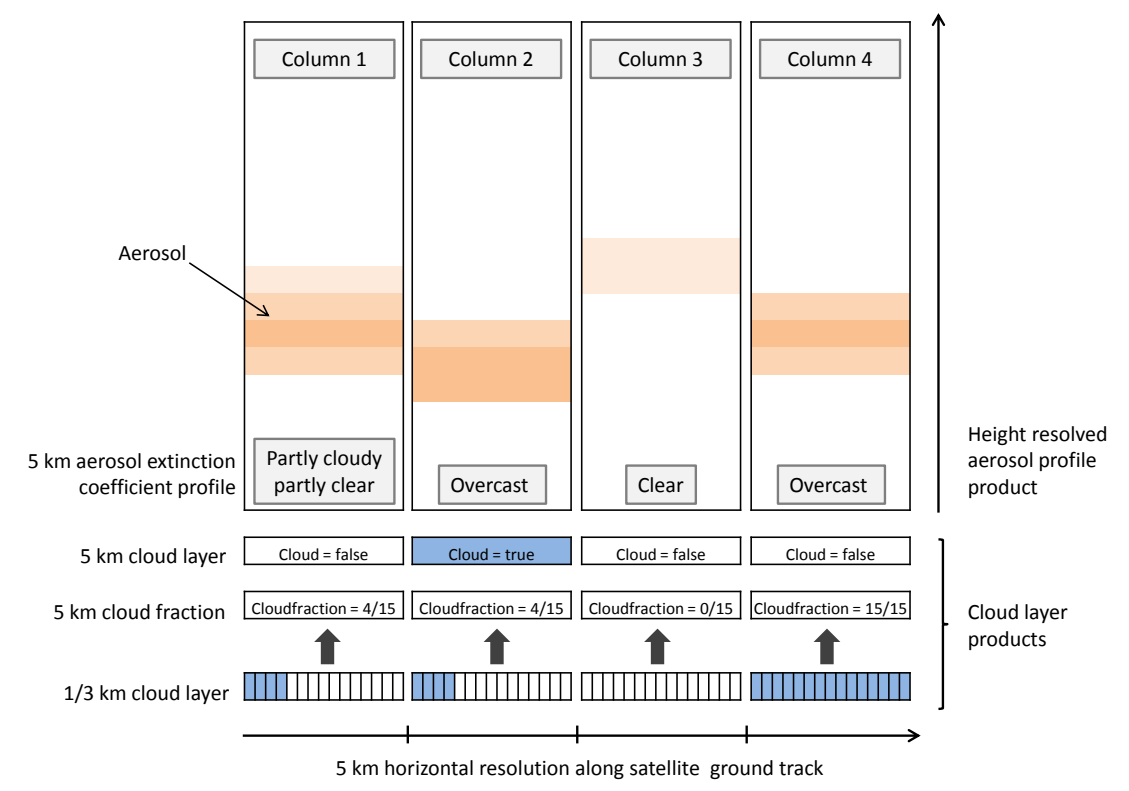

Figure 1. Illustration of the classification procedure of cloudy- and clear-sky aerosol extinction profiles. Only profiles where both the $1 / 3$ and $5 \mathrm{~km}$ cloud layer products indicate clear sky are classified as completely clear (column 3). Only profiles where either the $5 \mathrm{~km}$ cloud layer product indicates a cloud or the $1 / 3 \mathrm{~km}$ layer data indicate a $5 \mathrm{~km}$ cloud fraction equal to 1 are considered completely cloudy or overcast (columns 2 and 4 respectively). All profiles where the $5 \mathrm{~km}$ cloud layer product does not report a cloud, but the $5 \mathrm{~km}$ cloud fraction is larger than zero but less than 1, are considered partly cloudy and partly clear (column 1).

single lidar shot) are reported separately in the $1 / 3 \mathrm{~km}$ cloud layer product. Clouds detected in one single shot are typically optically thick boundary layer clouds, e.g., stratocumulus (Vaughan et al., 2009). However, in desert regions dense dust layers are sometimes detected in one single shot but are reported in the $1 / 3 \mathrm{~km}$ cloud layer product. Thus, part of the low clouds identified in these regions might be dust aerosols.

We use a combination of the 5 and $1 / 3 \mathrm{~km}$ cloud layer products to obtain the most accurate low-cloud distribution. A $5 \mathrm{~km}$ resolution low-cloud fraction is calculated from the $1 / 3 \mathrm{~km}$ cloud layer product (based on 15 consecutive single lidar shots) if the $5 \mathrm{~km}$ cloud layer product reports a cloudfree $5 \mathrm{~km}$ profile. Both the 5 and the $1 / 3 \mathrm{~km}$ cloud layer products contain information about the cloud-top height for every cloud layer, necessary for calculating the above cloud-top height AOD variables in this study. Only profiles free from middle and high clouds (i.e., clouds with tops above $680 \mathrm{hPa}$ ) are included in the analysis. Thus, we are not addressing the aerosols above low cloud but below high or middle cloud. Detecting multi-layer clouds from satellite sensors is possible (e.g., Huang et al., 2005, 2006) but addressing aerosols below cloud in CALIPSO retrievals creates additional uncertainties and challenges that are not very necessary to investigate the relationship between aerosol amount and underlying cloud.

The aerosol extinction coefficient at $532 \mathrm{~nm}$ from the twodimensional aerosol profile product is aggregated onto a three-dimensional grid with a horizontal latitude-longitude resolution of $2^{\circ} \times 5^{\circ}$. The $5 \mathrm{~km}$ horizontal resolution aerosol extinction profiles are separated into clear-sky profiles and profiles containing low clouds. The classification procedure is illustrated in Fig. 1. The aerosol extinction profiles for which the $5 \mathrm{~km}$ cloud layer product reports a cloud layer are categorized as overcast (column 2 in Fig. 1). However, profiles where the $5 \mathrm{~km}$ cloud layer product reports a cloud-free column can still contain cloud layers detected at higher resolution (i.e., clouds reported in the $1 / 3 \mathrm{~km}$ cloud layer product). If the $5 \mathrm{~km}$ cloud layer product reports a cloud-free $5 \mathrm{~km}$ profile, the $5 \mathrm{~km}$ resolution cloud fraction derived from the $1 / 3 \mathrm{~km}$ cloud layer product is checked. If this cloud fraction is one or zero, the profile is categorized as overcast (column 4 in Fig. 1) or cloud-free (column 3 in Fig. 1), respectively. If the $5 \mathrm{~km}$ cloud fraction is less than one but larger than zero, the aerosol extinction is weighted by the cloud fraction into clear and cloudy profiles accordingly (column 1 in Fig. 1). Two types of grid-cell average monthly mean aerosol extinction coefficient profiles, one cloudy and one clear sky, are then calculated for each $2^{\circ} \times 5^{\circ}$ grid cell, based on all the cloudy and clear $5 \mathrm{~km}$ aerosol extinction coefficient profiles collected in each $2^{\circ} \times 5^{\circ}$ grid cell during 1 month.

The two types of monthly mean aerosol extinction coefficient profiles are integrated through the atmosphere down to the maximum low-cloud-top height found in each $2^{\circ} \times 5^{\circ}$ grid cell for each month and year. The maximum low-cloudtop height is defined as the single largest value of the lowcloud-top heights found in a $2^{\circ} \times 5^{\circ}$ grid cell, considering 
(a) All aerosols DJF, day

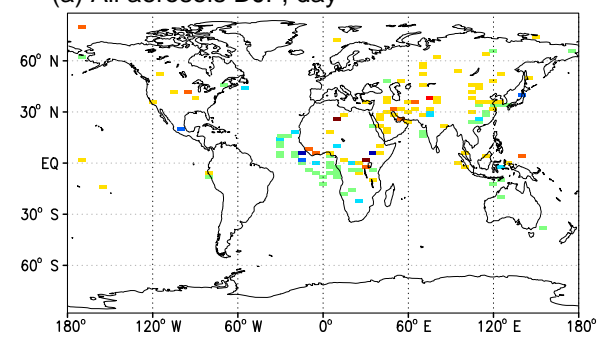

(c) All aerosols JJA, day

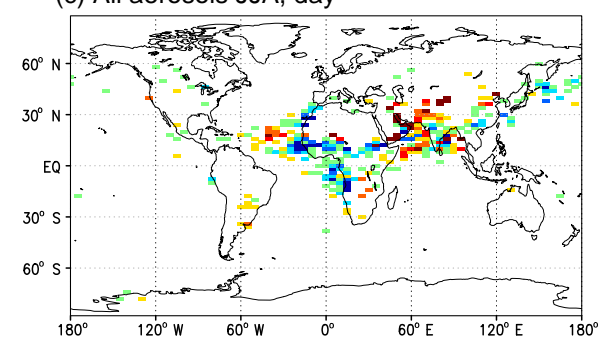

(b) All aerosols MAM, day

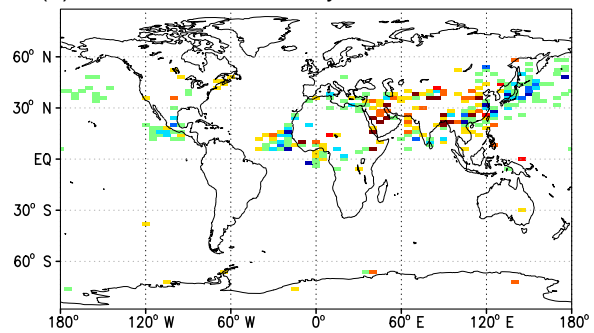

(d) All aerosols SON, day

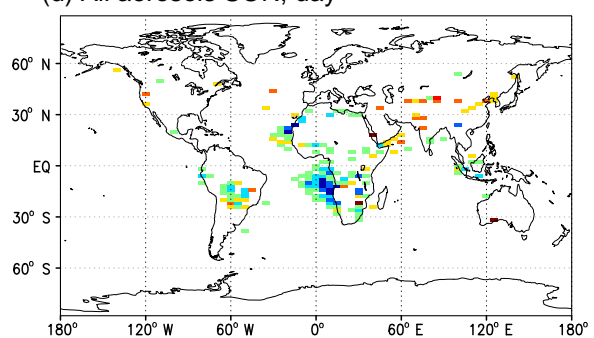

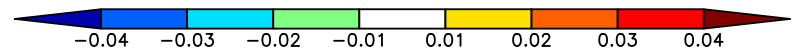

Figure 2. Daytime difference between AOD above the maximum low-cloud-top height over low clouds and the AOD above the same height in the clear-sky neighborhoods for (a) DJF, (b) MAM, (c) JJA, and (d) SON. Positive values mean that the aerosols above low clouds have a larger AOD than that in the clear-sky portion of the grid cell.

both the $1 / 3$ and $5 \mathrm{~km}$ resolution cloud data. The maximum low-cloud-top height is chosen as the reference height to eliminate spurious effect arising from aerosol sampling deficiencies in cloudy profiles at altitudes below the maximum cloud-top height. Thus, a grid-cell average AOD above low clouds and an AOD in clear sky are derived above the same maximum low-cloud-top height detected in each $2^{\circ} \times 5^{\circ}$ grid cell. The AOD integrated down to the maximum lowcloud-top height, both in clear sky and when low clouds are detected, will hereafter be referred to as $\mathrm{AOD}_{\mathrm{ct}} . \triangle \mathrm{AOD}_{\mathrm{ct}}$ here will designate the difference between $\mathrm{AOD}_{\mathrm{ct}}$ above low clouds and $\mathrm{AOD}_{\mathrm{ct}}$ in clear sky, and positive values mean that $\mathrm{AOD}_{\mathrm{ct}}$ above low clouds is larger than $\mathrm{AOD}_{\mathrm{ct}}$ in clear sky.

In addition to the AOD, we calculate the low-cloud fraction for each $2^{\circ} \times 5^{\circ}$ grid cell. This two-dimensional lowcloud fraction is derived from the fraction of $5 \mathrm{~km}$ resolution profiles that contain low clouds combined with the $5 \mathrm{~km}$ resolution low-cloud fraction derived from the $1 / 3 \mathrm{~km}$ cloud layer product described above.

We apply a data quality control similar to that of Winker et al. (2013). Only aerosol or cloud samples with a cloud aerosol discrimination (CAD) score with an absolute value equal to or greater than 20 are used in the analysis. Moreover, we screen the data for the extinction quality control (QC) flag. Only samples with QC values corresponding to $0,1,16$, and 18 are included in the analysis (see Winker et al., 2013). Screening for extinction uncertainty is done to ensure that profiles containing samples with an uncertainty of
$99.9 \mathrm{~km}^{-1}$, which indicates failed retrieval with respect to the uncertainty estimate, are not included.

\section{Results}

Figures 2 and 6 display the multi-year seasonal average difference between AOD above the maximum low-cloud-top height when and where low clouds are present and AOD above the same height in clear sky, denoted here as $\triangle \mathrm{AOD}_{\mathrm{ct}}$. A large number of cloudy and clear air profiles were used to derive the $\mathrm{AOD}_{\mathrm{ct}}$. Figure 3 shows how many profiles were used over each grid box. The maximum low-cloud-top height from daytime retrievals is shown in Fig. 4. Only the grid boxes where the numbers of cloudy and clear profiles are both larger than $5 \%$ of the total number of profiles in the grid box are shown in Figs. 2 and 6. Thus, many of the potentially spurious cloud samples over desert regions (see Sect. 2), where the low-cloud fraction (shown in Fig. 5) is small, are removed. We also exclude the grid boxes in Figs. 2 and 6 that have $\triangle \mathrm{AOD}_{\mathrm{ct}}<1.00 \times 10^{-2}$.

The daytime difference between $\mathrm{AOD}_{\mathrm{ct}}$ above low clouds and $\mathrm{AOD}_{\mathrm{ct}}$ in clear sky, as shown in Fig. 2, displays both large-scale spatial patterns and seasonal variations. The difference is most pronounced in the tropical regions, where the $\mathrm{AOD}_{\mathrm{ct}}$ above low clouds is largest. The nighttime $\triangle \mathrm{AOD}_{\mathrm{ct}}$ (Fig. 6) is generally smaller and noisier than the daytime $\triangle \mathrm{AOD}_{\mathrm{ct}}$ field. Similar to the daytime global $\triangle \mathrm{AOD}_{\mathrm{ct}}$ distribution, the nighttime $\mathrm{AOD}_{\mathrm{ct}}$ difference between cloudy and 
(a) No. of clear-sky profiles (daytime)

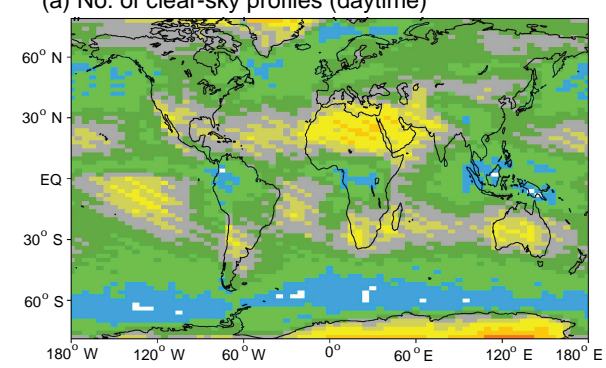

(c) No. of clear-sky profiles (nighttime)

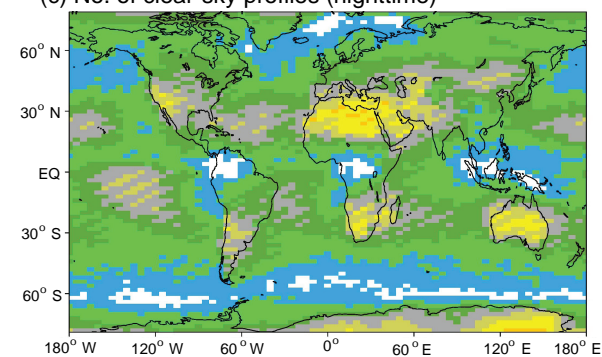

(b) No. of over-cloud profiles (daytime)

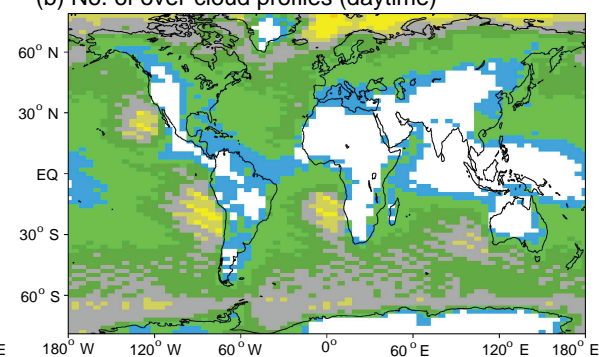

(d) No. of over-cloud profiles (nighttime)

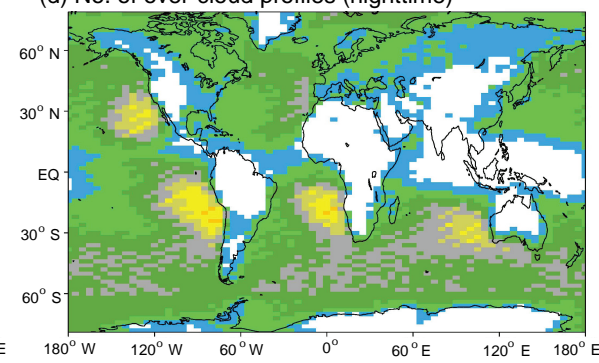

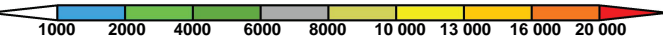

Figure 3. Number of profiles used for the analysis over each $2^{\circ} \times 5^{\circ}$ latitude-longitude grid box. These numbers represent the total available profiles from June 2006 to October 2011.

(a) Maximum low cloud top height DJF
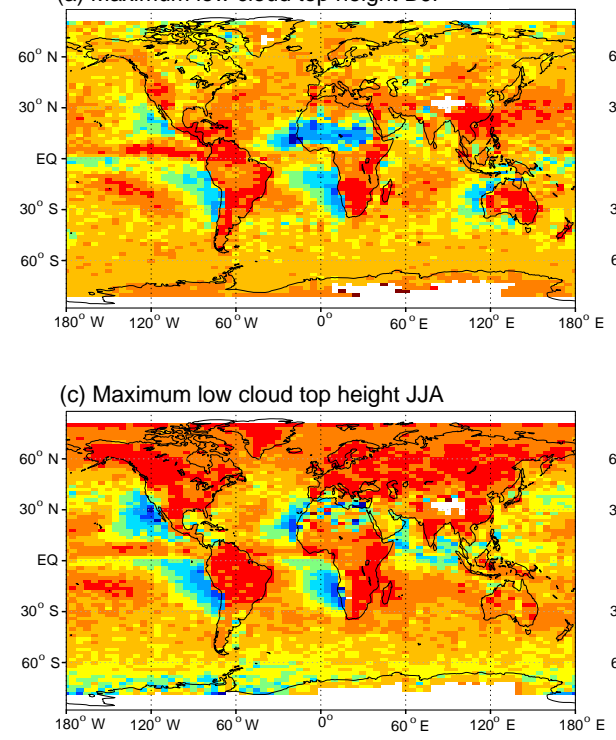

(b) Maximum low cloud top height MAM

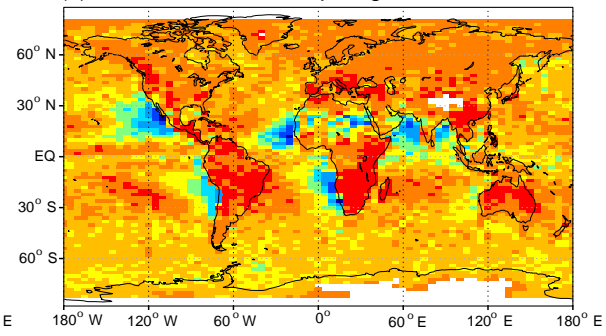

(d) Maximum low cloud top height SON

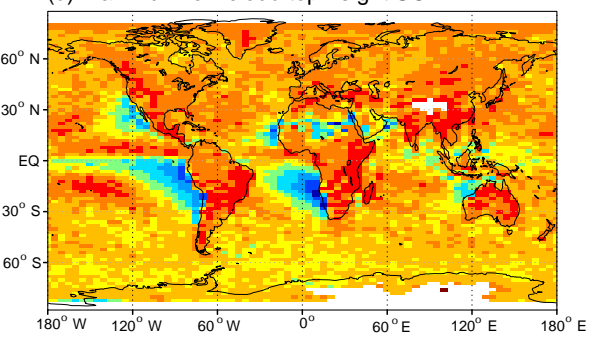

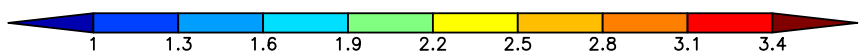

Figure 4. Daytime maximum low-cloud-top height (km) for (a) DJF, (b) MAM, (c) JJA, and (d) SON.

clear skies is mainly concentrated in the tropical regions, except during March, April, and May (MAM) and June, July, and August (JJA), when pronounced $\mathrm{AOD}_{\mathrm{ct}}$ differences between cloudy and clear sky are found also in the Northern Hemisphere extratropics. The nighttime $\mathrm{AOD}_{\mathrm{ct}}$ above low clouds also shows higher values in the Northern Hemisphere extratropical regions compared to that derived from daytime retrievals.

Are $\triangle \mathrm{AOD}_{\mathrm{ct}}$ values in Figs. 2 and 6 statistically significant? Applying Student's $t$ test to each grid box, as commonly done in the literature, we find that they are not significant. However, we need to note that applying Student's 

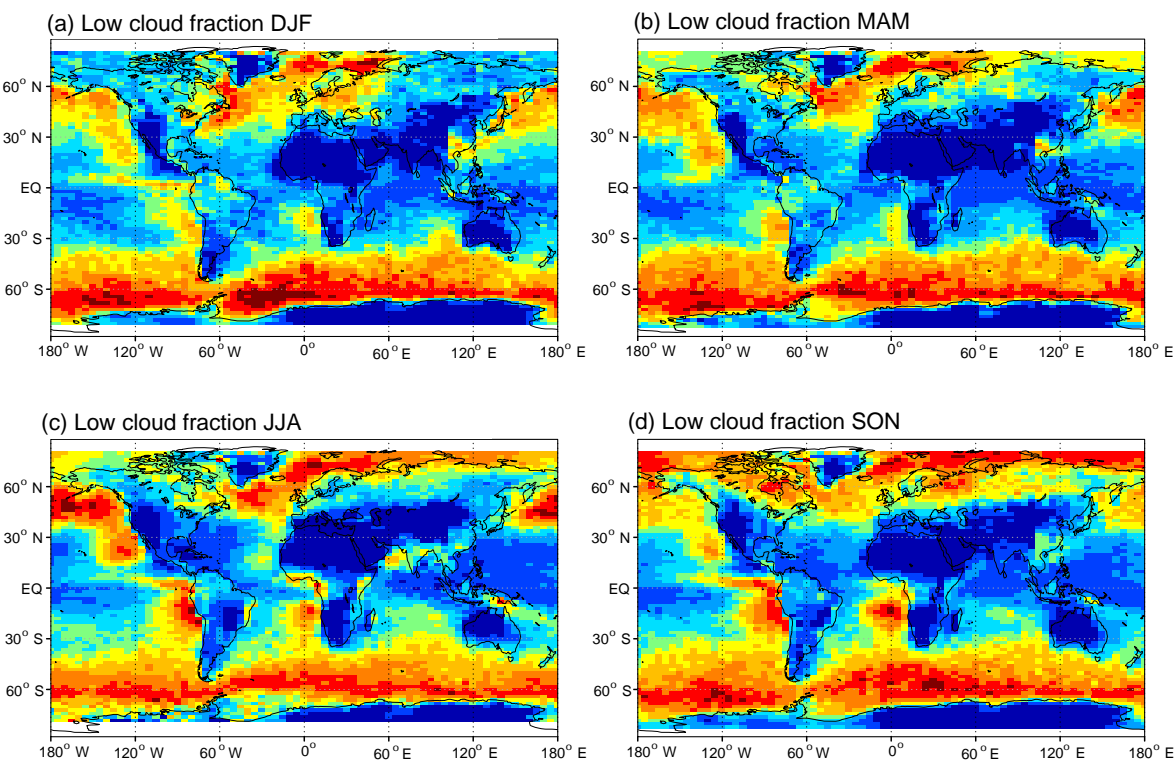

(d) Low cloud fraction SON
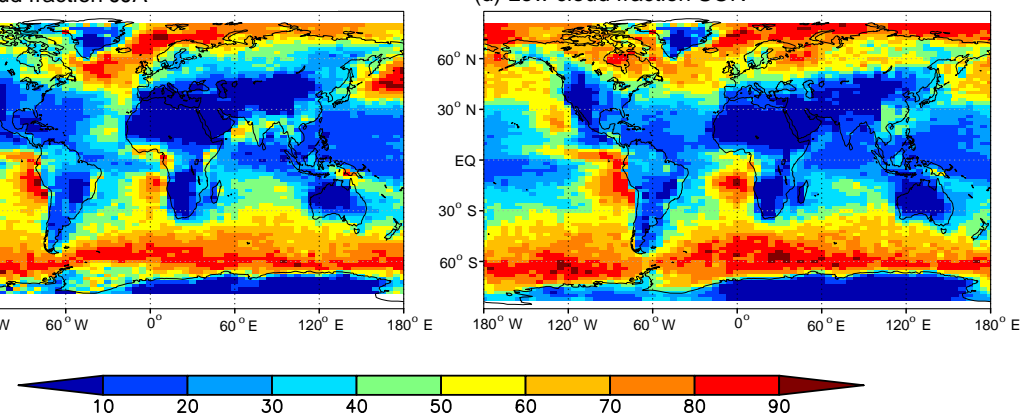

Figure 5. Daytime low-cloud fraction (in \%) calculated from profiles not containing middle and high clouds for (a) DJF, (b) MAM, (c) JJA, and (d) SON.

(a) All aerosols DJF, night
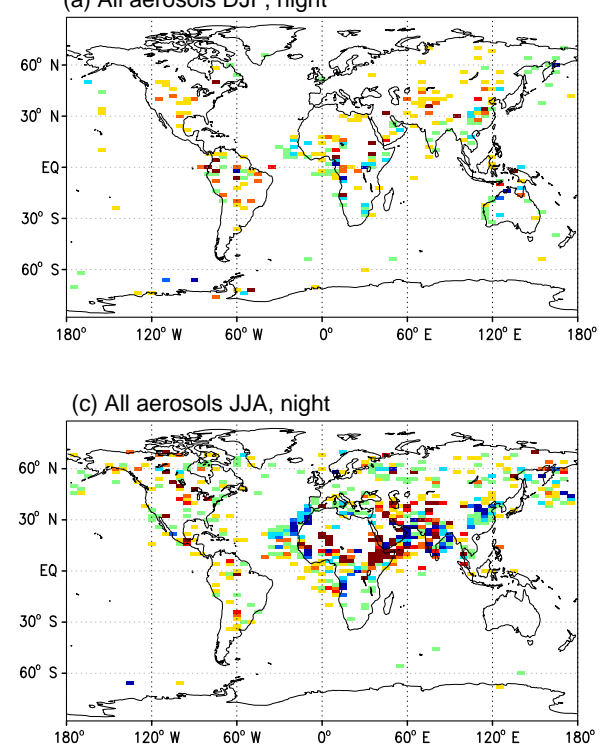

(b) All aerosols MAM, night

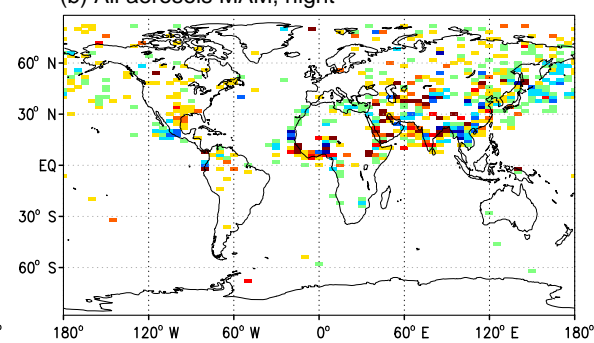

(d) All aerosols SON, night

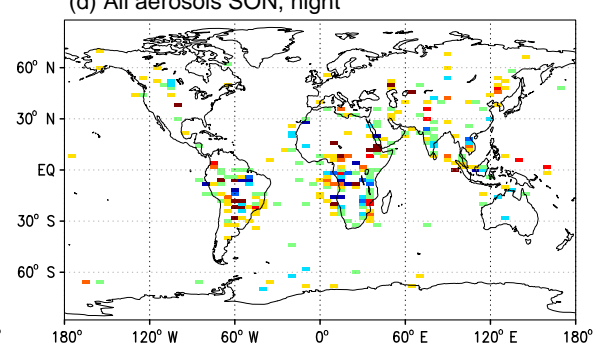

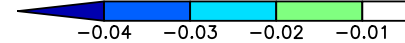

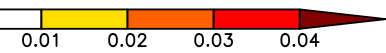

Figure 6. Same as Fig. 2 except for nighttime difference.

$t$ test to each grid assumes that grids are independent of each other (Decremer et al., 2014), which is not correct. When grids are related, the bar for significance should be lower than when grids are independent, meaning that applying Student's $t$ test to each grid could determine actually significant values to be statistically insignificant. Some of the $\Delta \mathrm{AOD}_{\mathrm{ct}}$ val- ues in Figs. 2 and 6 have large-scale spatial patterns, which means that grids are related to each other. Attempts have been made to address spatial correlation in the statistics community (Elmore et al., 2006), but such techniques cannot be used to determine the significance of local features. Thus, we first test the significance of the global average of daytime 
$\triangle \mathrm{AOD}_{\mathrm{ct}}$ since the global average does not suffer the aforementioned grid-dependence issue. We find that the global average of $\triangle \mathrm{AOD}_{\mathrm{ct}}$ is largest in September and also statistically significant using a one-sided $95 \%$ confidence interval in this calendar month, while statistically insignificant in the other months. If we limit the average to the $20^{\circ} \mathrm{W}-20^{\circ} \mathrm{E}$ and $30^{\circ} \mathrm{S}$-Equator area, where daytime $\triangle \mathrm{AOD}_{\mathrm{ct}}$ is very large, the average of daytime $\Delta \mathrm{AOD}_{\mathrm{ct}}$ is statistically significant in September and also November. Please note that an area average other a global average can still be related to the average of another region (though the relation would probably be less than using each grid) and so the standard significance testing is likely to underestimate the significance in this case. Overall, we conclude that $\triangle \mathrm{AOD}_{\mathrm{ct}}$ contains statistically significant features.

The global average $\mathrm{AOD}_{\mathrm{ct}}$ above low clouds is much larger during the nighttime than during the daytime for all seasons (Table 1), which is most likely related to a higher $S / N$ for nighttime retrievals compared to those during the daytime. The seasonal global mean values range from 0.011 to 0.029 for nighttime $\mathrm{AOD}_{\mathrm{ct}}$ above low clouds and between 0.007 and 0.020 for that from daytime retrievals. Both the nighttime and daytime $\mathrm{AOD}_{\mathrm{ct}}$ above low clouds are largest in JJA. The global average $\triangle \mathrm{AOD}_{\mathrm{ct}}$ (calculated for grid boxes where the cloud fraction and clear air fraction exceeds $5 \%$ ) from nighttime retrievals is positive for all seasons, while the opposite is true for that from daytime retrievals (Table 2). This finding remains unaffected even if all the grid boxes are included in the calculation. As Table 2 shows, the daytime global average is largest during SON, at $-6.01 \times 10^{-3}$, and that for nighttime is largest during MAM, at $2.22 \times 10^{-3}$.

We further analyze the results in Figs. 2 and 6 by region and aerosol type. The aerosol types identified by the CALIPSO aerosol extinction retrieval algorithm (see Sect. 2) that contribute significantly to the global daytime $\mathrm{AOD}_{\mathrm{ct}}$ above low clouds are dust, smoke, and polluted dust (Table 1). The clean and polluted continental and clean marine aerosols, i.e., the other types, contribute negligibly to the daytime $\mathrm{AOD}_{\mathrm{ct}}$. Dust is the aerosol type that contributes the largest fraction to the daytime $\mathrm{AOD}_{\mathrm{ct}}$ above low clouds, with up to 65 and $70 \%$ in MAM and JJA, respectively. Dust also dominates the daytime $\mathrm{AOD}_{\mathrm{ct}}$ difference between clear sky and above low clouds, particularly in the abovementioned seasons. Over most parts of North Africa and the Arabian Peninsula, the $\mathrm{AOD}_{\mathrm{ct}}$ above low clouds is substantially higher than that in clear sky. However, the dust $\mathrm{AOD}_{\mathrm{ct}}$ is mainly found over desert regions where the low-cloud fraction is less than $5 \%$, and thus $\triangle \mathrm{AOD}_{\mathrm{ct}}$ over most desert regions is not included in Figs. 2 and 6. AOD $\mathrm{Ct}_{\mathrm{ct}}$ above low clouds is typically lower than $\mathrm{AOD}_{\mathrm{ct}}$ in clear sky where dust is transported over the Atlantic Ocean, except over the central tropical Atlantic Ocean in JJA (Fig. 7c). Dust aerosol transported over the Arabian Sea, on the other hand, has generally higher $\mathrm{AOD}_{\mathrm{ct}}$ above low clouds than in clear sky. These daytime results for dust $\triangle \mathrm{AOD}_{\mathrm{ct}}$ are mostly consistent with the
Table 1. Global and seasonal averages of $\mathrm{AOD}_{\mathrm{ct}}$ above low clouds for nighttime and daytime and the fraction of the daytime data that is classified as dust, smoke, or polluted dust.

\begin{tabular}{lcccccc}
\hline & \multicolumn{2}{c}{ Night } & & \multicolumn{3}{c}{ Day } \\
\cline { 2 - 5 } \cline { 5 - 7 } & AOD $_{\text {ct }}$ & & AOD $_{\text {ct }}$ & Dust & Smoke & Polluted dust \\
\hline DJF & 0.011 & & 0.007 & $34 \%$ & $17 \%$ & $43 \%$ \\
MAM & 0.021 & & 0.015 & $65 \%$ & $8 \%$ & $24 \%$ \\
JJA & 0.029 & & 0.020 & $70 \%$ & $12 \%$ & $16 \%$ \\
SON & 0.019 & & 0.010 & $47 \%$ & $23 \%$ & $27 \%$ \\
\hline
\end{tabular}

Table 2. Global and seasonal averages of $\triangle \mathrm{AOD}_{\mathrm{ct}}$ for nighttime and daytime. The average is made over the grid cells where the $\triangle \mathrm{AOD}_{\mathrm{ct}}$ is $>1.00 \times 10^{-2}$, and the low-cloud fraction and clear-sky fraction are both $>5 \%$. The numbers in parentheses are the averages over all grid cells where the cloud fraction and clear air fraction are both $>5 \%$, irrespective of the magnitude of $\triangle \mathrm{AOD}_{\mathrm{ct}}$.

\begin{tabular}{lcc}
\hline & \multicolumn{1}{c}{ Night } & Day \\
\cline { 2 - 3 } & $\Delta \mathrm{AOD}_{\mathrm{ct}} \times 10^{-3}$ & $\Delta \mathrm{AOD}_{\mathrm{ct}} \times 10^{-3}$ \\
\hline DJF & $1.91(0.24)$ & $-2.06(-0.00)$ \\
MAM & $2.22(0.22)$ & $-3.00(-0.44)$ \\
JJA & $1.60(0.24)$ & $-3.64(-0.52)$ \\
SON & $1.06(0.10)$ & $-6.01(-0.61)$ \\
\hline
\end{tabular}

nighttime $\triangle \mathrm{AOD}_{\mathrm{ct}}$ results, although the nighttime $\mathrm{AOD}_{\mathrm{ct}}$ has not been separated for different aerosol types.

In the boreal spring, dust and pollution are transported from the Eurasian continent over to the North Pacific Ocean (e.g., VanCuren, 2003; Husar et al., 2001; Merrill et al., 1989). Over the northeastern Pacific Ocean, the daytime $\mathrm{AOD}_{\mathrm{ct}}$ above low clouds due to polluted and pure dust is lower than the clear-sky $\mathrm{AOD}_{\mathrm{ct}}$ for these aerosol types (Fig. 7a and b). This difference can be observed in both MAM and JJA. A similar AOD $_{\text {ct }}$ difference for all aerosols between cloudy and clear skies is also visible in the nighttime data (Fig. $6 \mathrm{~b}$ and c). Pollution over India contains aerosols from fossil fuel combustion and biomass burning (Gustafsson et al., 2009). The main contributions to the daytime $\mathrm{AOD}_{\mathrm{ct}}$ above low clouds in this region come from aerosols identified as polluted and pure dust in the CALIPSO data. The daytime dust $\mathrm{AOD}_{\mathrm{ct}}$ above low clouds is lower than $\mathrm{AOD}_{\mathrm{ct}}$ in clear sky over India in JJA (Fig. 7c). Over eastern China, where fossil fuel combustion is the dominant aerosol source (Chen et al., 2013), the $\mathrm{AOD}_{\mathrm{ct}}$ consists of contributions from smoke, dust, and polluted dust. However, the daytime $\triangle \mathrm{AOD}_{\mathrm{ct}}$ field over China is generally noisy. Similarly, the nighttime $\triangle \mathrm{AOD}_{\mathrm{ct}}$ field over southern and eastern Asia shows large spatial variations.

During the biomass burning season in southern Africa (August to October), smoke aerosol is advected over the tropical southeastern Atlantic Ocean (e.g., Anderson et al., 1996; Edwards et al., 2006). Large amounts of low cloud in combi- 

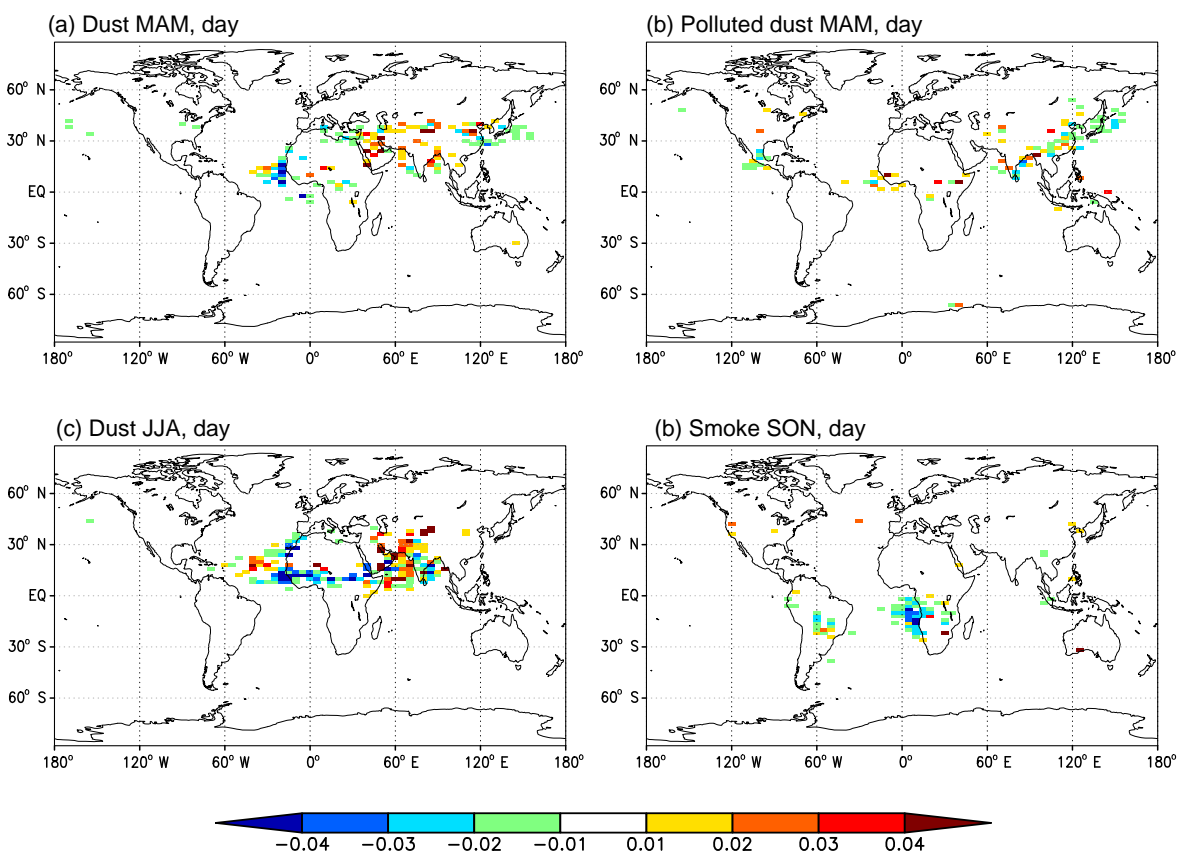

Figure 7. Same as Fig. 2 except for (a) dust MAM, (b) polluted dust MAM, (c) dust JJA, and (d) smoke SON.

nation with the absorbing properties of smoke from biomass burning make this region one of the particular interest for quantifying AOD above clouds. In September, October, and November (SON), daytime smoke $\mathrm{AOD}_{\mathrm{ct}}$ above low clouds derived from the CALIPSO data is lower than that in clear sky in this region (Fig. 7d). This is also the season when the magnitude of global average daytime $\Delta \mathrm{AOD}_{\mathrm{ct}}$ is largest (Table 2) and the contribution from smoke aerosol to the total daytime $\mathrm{AOD}_{\mathrm{ct}}$ above low clouds is largest: $23 \%$ (Table 1). However, a corresponding difference is not visible in the data from nighttime retrievals (Fig. 6d).

Similar to the daytime smoke $\mathrm{AOD}_{\mathrm{ct}}$ difference over the tropical Atlantic Ocean, the daytime smoke $\mathrm{AOD}_{\mathrm{ct}}$ in clear sky is larger than above low cloud over the South American continent, another region where biomass burning aerosols are emitted during SON. The corresponding nighttime $\triangle \mathrm{AOD}_{\mathrm{ct}}$ in this region is noisier than the daytime $\triangle \mathrm{AOD}_{\mathrm{ct}}$.

\section{Discussion and conclusions}

Like any observations, CALIPSO data are subject to uncertainties. That said, we have offered the observational quantification of the difference between AOD above low-cloudtop height in the clear-sky portions of a $2^{\circ} \times 5^{\circ}$ grid box and in the low-cloud-occupied portions of the same grid box over the globe.

The spatial distribution of the daytime difference between $\mathrm{AOD}_{\mathrm{ct}}$ (i.e., AOD above cloud-top height) in clear sky and above low clouds is found not to be random. Over ocean regions where low-cloud fraction is large (i.e., the tropical southeast Atlantic Ocean and northeast Pacific Ocean), the daytime $\mathrm{AOD}_{\mathrm{ct}}$ in clear sky typically exceeds that above low clouds. These are also the areas where aerosols are frequently observed above clouds (Devasthale and Thomas, 2011).

In general, daytime $\mathrm{AOD}_{\mathrm{ct}}$ above low clouds is smaller than that in clear sky. The largest global average seasonal daytime difference is $-6.01 \times 10^{-3}$ during SON. On the other hand, the nighttime seasonal global average $\mathrm{AOD}_{\mathrm{ct}}$ above cloud is larger than that in clear skies, and the largest global average seasonal difference is $2.22 \times 10^{-3}$ in MAM. However, the nighttime $\triangle \mathrm{AOD}_{\mathrm{ct}}$ spatial distribution is noisier than that derived from daytime data, and the magnitude of the nighttime global average $\triangle \mathrm{AOD}_{\mathrm{ct}}$ is smaller than the corresponding daytime values.

The results presented in this study indicate that daytime AOD above low clouds is generally lower than that in clear sky at the same height over, for example, the southeastern Atlantic Ocean during SON. The local $\mathrm{AOD}_{\mathrm{ct}}$ above low clouds is up to 0.04 lower than that in clear sky in this region. As discussed in Sect. 1, a possibility exists that aerosol amounts over cloud can be different to those in nearby clear sky by involving either cloud-aerosol interactions or large-scale circulation patterns. However, a corresponding difference cannot be seen in the $\triangle \mathrm{AOD}_{\mathrm{ct}}$ derived from nighttime retrievals. This could indicate a bias in CALIPSO retrieval. The detection threshold in the feature detection algorithm varies depending on the background lighting conditions and thus on the presence of clouds as well as the surface albedo during the daytime (see Hunt et al., 2009; Vaughan et al., 2009; 
Chepfer et al., 2013; Kacenelenbogen et al., 2014). This means that the daytime $\mathrm{AOD}_{\mathrm{ct}}$ above low bright clouds reported here might be underestimated compared to the $\mathrm{AOD}_{\mathrm{ct}}$ in clear sky in the same grid cell. Thus, the negative daytime $\triangle \mathrm{AOD}_{\mathrm{ct}}$ might simply be a result of systematic differences between the detection thresholds in clear sky and above low bright clouds. Moreover, it is possible that the lower albedo of the ocean surface compared to that of land enhances the $\mathrm{AOD}_{\mathrm{ct}}$ bias between clear and cloudy sky over the ocean. The absence of a pronounced difference between the $\mathrm{AOD}_{\mathrm{ct}}$ above low cloud and the $\mathrm{AOD}_{\mathrm{ct}}$ in clear sky over the southeastern Atlantic Ocean during SON derived from nighttime retrievals is consistent with this conjecture.

On the other hand, over the northwest Pacific Ocean in MAM, the nighttime results are in agreement with the daytime results that $\mathrm{AOD}_{\mathrm{ct}}$ above low clouds is lower than that in clear sky. It is very difficult to imagine that the possible bias in CALIPSO retrieval is limited to the southeastern Atlantic Ocean. In fact, boundary layer clouds in the southeastern Atlantic Ocean are known to exhibit a strong diurnal cycle (Rozendaal et al., 1995; Wood et al., 2002; Min and Zhang, 2014). Thus, the $\triangle \mathrm{AOD}_{\mathrm{ct}}$ day and night discrepancy over this region could be a real phenomenon rather than a byproduct of imperfect CALIPSO retrievals, due to the aerosol-cloud interaction through shortwave radiation, as discussed in Sect. 1. There is no shortwave radiation during the night.

A solution to settle this uncertainty could be to apply a similar approach to that of Chepfer et al. (2013), who used a fixed detection threshold, which exceeds the variable detection threshold in the standard data processing algorithm, to derive an alternative cloud climatology from the CALIPSO backscatter data. The method requires a reprocessing of the level 1 backscatter data to obtain a new level 2 aerosol extinction data set. Deriving this alternative aerosol extinction level 2 data is not trivial, but probably necessary, for an unbiased comparison of daytime $\mathrm{AOD}_{\mathrm{ct}}$ above low clouds and in clear sky.

If the amount of aerosols over cloud indeed differs from that at the same heights in nearby clear sky, what would this mean to atmospheric science for the future? If one is interested in computing observation-constrained aerosol direct forcing using satellite-derived AOD (such as MODIS AOD), he/she needs to adjust the amount of aerosol over cloud using observations. As mentioned in Sect. 1, there already exist various products of the AOD above cloud retrieved from various passive sensors (such as MODIS, POLDER, and OMI) and CALIOP (see Jethva et al., 2014, for the list). Beyond the estimation of aerosol direct forcing, the idea of cloud influencing the amount of overlying aerosols is very new and requires further scientific investigations for the mechanisms.

Acknowledgements. This study was funded by the National Science Foundation (AGS-1455759). Data were obtained from NASA Langley Research Center Atmospheric Science Data Center. We thank the ICARE Data and Services Center for providing access to data used in this study.

Edited by: J. Huang

\section{References}

Anderson, B. E., Grant, W. B., Gregory, G. L., Browell, E. V., Collins Jr., J. E., Sachse, G. W., Bagwell, D. R., Hudgins, C. H., Blake, D. R., and Blake, N. J.: Aerosols from biomass burning over the tropical South Atlantic region: Distributions and impacts, J. Geophys. Res.-Atmos., 101, 24117-24138, 1996.

Chand, D., Anderson, T. L., Wood, R., Charlson, R. J., Hu, Y., Liu, Z., and Vaughan, M.: Quantifying above-cloud aerosol using spaceborne lidar for improved understanding of cloudy-sky direct climate forcing, J. Geophys. Res.-Atmos., 113, D13206, doi:10.1029/2007JD009433, 2008.

Chand, D., Wood, R., Anderson, T. L., Satheesh, S. K., and Charlson, R. J.: Satellite-derived direct radiative effect of aerosols dependent on cloud cover, Nat. Geosci., 2, 181-184, 2009.

Chen, B., Andersson, A., Lee, M., Kirillova, E. N., Xiao, Q., Kruså, M., Shi, M., Hu, K., Lu, Z., Streets, D. G., Du, K., and Gustafsson, Ö.: Source Forensics of Black Carbon Aerosols from China, Environ. Sci. Technol., 47, 9102-9108, 2013.

Chepfer, A., Cesana, G., Winker, M. A., Getzewich, B., Vaughan, K. A., and Liu, Z.: Comparison of two different cloud climatologies derived from CALIOP-attenuated backscattered measurements (Level 1): The CALIPSO-ST and the CALIPSO-GOCCP, J. Atmos. Ocean. Tech., 30, 725-744, 2013.

Choi, J.-O. and Chung, C. E.: Sensitivity of aerosol direct radiative forcing to aerosol vertical profile, Tellus B, 66, 24376, doi:10.3402/tellusb.v66.24376, 2014.

Chung, C. E., Ramanathan, V., Kim, D., and Podgorny, I. A.: Global anthropogenic aerosol direct forcing derived from satellite and ground-based observations, J. Geophys. Res., 110, D24207, doi:10.1029/2005JD006356, 2005.

Costantino, L. and Bréon, F.-M.: Analysis of aerosol-cloud interaction from multi-sensor satellite observations, Geophys. Res. Lett., 37, L11801, doi:10.1029/2009GL041828, 2010.

Costantino, L. and Bréon, F.-M.: Aerosol indirect effect on warm clouds over South-East Atlantic, from co-located MODIS and CALIPSO observations, Atmos. Chem. Phys., 13, 69-88, doi:10.5194/acp-13-69-2013, 2013.

Decremer, D., Chung, C. E., Ekman, A. M. L., and Brandefelt, J.: Which significance test performs the best in climate simulations?, Tellus A, 66, 23139, doi:10.3402/tellusa.v66.23139, 2014.

Devasthale, A. and Thomas, M. A.: A global survey of aerosol-liquid water cloud overlap based on four years of CALIPSO-CALIOP data, Atmos. Chem. Phys., 11, 1143-1154, doi:10.5194/acp-11-1143-2011, 2011.

Edwards, D., Emmons, L., Gille, J., Chu, D. A., Attié, J., Giglio, L., Wood, S. W., Haywood, J., Deeter, M., Massie, S., Ziskin, D. C., and Drummond, J.: Satellite-observed pollution from Southern Hemisphere biomass burning, J. Geophys. Res., 111, D14312, doi:10.1029/2005JD006655, 2006.

Elmore, K. L., Baldwin, M. E., and Schultz, D. M.: Field Significance Revisited: Spatial Bias Errors in Forecasts as Applied to the Eta Model, Mon. Weather Rev., 134, 519-531, 2006. 
Gustafsson, Ö., Kruså, M., Zencak, Z., Sheesley, R. J., Granat, L., Engström, E., Praveen, P. S., Rao, P. S. P., Leck, C., and Rodhe, H.: Brown Clouds over South Asia: Biomass or Fossil Fuel Combustion?, Science, 323, 495-498, 2009.

Haywood, J. M. and Shine, K. P.: Multi-spectral calculations of the direct radiative forcing of tropospheric sulphate and soot aerosols using a column model, Q. J. Roy. Meteorol. Soc., 123, 19071930, 1997.

Haywood, J. M., Osborne, S. R., and Abel, S. J.: The effect of overlying absorbing aerosol layers on remote sensing retrievals of cloud effective radius and cloud optical depth, Q. J. Roy. Meteor. Soc., 130, 779-800, 2004.

Hu, Y., Winker, D., Vaughan, M., Lin, B., Omar, A., Trepte, C., Flittner, D., Yang, P., Nasiri, S. L., Baum, B., Holz, R., Sun, W., Liu, Z., Wang, Z., Young, S., Stamnes, K., Huang, J., and Kuehn, R.: CALIPSO/CALIOP Cloud Phase Discrimination Algorithm, J. Atmos. Ocean. Tech., 26, 2293-2309, 2009.

Huang, J., Minnis, P., Lin, B., Yi, Y., Khaiyer, M. M., Arduini, R. F., Fan, A., and Mace, G. G.: Advanced retrievals of multilayered cloud properties using multispectral measurements, J. Geophys. Res.-Atmos., 110, D15S18, doi:10.1029/2004JD005101, 2005.

Huang, J., Minnis, P., Lin, B., Yi, Y., Fan, T. F., Sun-Mack, S., and Ayers, J. K.: Determination of ice water path in ice-over-water cloud systems using combined MODIS and AMSR-E measurements, Geophys. Res. Lett., 33, L21801, doi:10.1029/2006GL027038, 2006.

Hunt, W. H., Winker, M. A., Vaughan, K. A., Powell, K. A., Lucker, P. L., and Weimer, C.: CALIPSO Lidar description and performance assessment, J. Atmos. Ocean. Tech., 26, 1214-1228, 2009

Husar, R. B., Tratt, D. M., Schichtel, B. A., Falke, S. R., Li, F., Jaffe, D., Gassó, S., Gill, T., Laulainen, N. S., Lu, F., Reheis, M. C., Chun, Y., Westphal, D., Holben, B. N., Gueymard, C., McKendry, I., Kuring, N., Feldman, G. C., McClain, C., Frouin, R. J., Merrill, J., DuBois, D., Vignola, F., Murayama, T., Nickovic, S., Wilson, W. E., Sassen, K., Sugimoto, N., and Malm, W. C.: Asian dust events of April 1998, J. Geophys. Res.-Atmos., 106, 18317-18330, 2001

Jethva, H., Torres, O., Waquet, F., Chand, D., and Hu, Y.: How do A-train sensors intercompare in the retrieval of above-cloud aerosol optical depth? A case study-based assessment, Geophys. Res. Lett., 41, 186-192, 2014.

Johnson, B. T., Shine, K. P., and Forster, P. M.: The semi-direct aerosol effect: Impact of absorbing aerosols on marine stratocumulus, Q. J. Roy. Meteor. Soc., 130, 1407-1422, 2004.

Kacenelenbogen, M., Redemann, J., Vaughan, M. A., Omar, A. H., Russell, P. B., Burton, S., Rogers, R. R., Ferrare, R. A., and Hostetler, C. A.: An evaluation of CALIOP/CALIPSO's aerosolabove-cloud (AAC) detection and retrieval capability, J. Geophys. Res.-Atmos., 119, 230-244, 2014.

Knobelspiesse, K., Cairns, B., Redemann, J., Bergstrom, R. W., and Stohl, A.: Simultaneous retrieval of aerosol and cloud properties during the MILAGRO field campaign, Atmos. Chem. Phys., 11, 6245-6263, doi:10.5194/acp-11-6245-2011, 2011.

Liu, Z., Omar, A., Hu, Y., Vaughan, M., and Winker, D. M.: CALIOP algorithm theoretical basis document - part 3: Scence classification algorithms. Release 1.0, NASA Langeley Research Center, PC-SCI-202 ERL402-NHELM2, Hampton, VA, USA, 2005.
Liu, Z., Vaughan, M., Winker, D., Kittaka, C., Getzewich, B., Kuehn, R., Omar, A., Powell, K., Trepte, C., and Hostetler, C.: The CALIPSO Lidar Cloud and Aerosol Discrimination: Version 2 Algorithm and Initial Assessment of Performance, J. Atmos. Ocean. Tech., 26, 1198-1213, 2009.

Liu, Z., Winker, D., Omar, A., Vaughan, M., Kar, J., Trepte, C., $\mathrm{Hu}, \mathrm{Y}$., and Schuster, G.: Evaluation of CALIOP $532 \mathrm{~nm}$ aerosol optical depth over opaque water clouds, Atmos. Chem. Phys., 15, 1265-1288, doi:10.5194/acp-15-1265-2015, 2015.

Mauger, G. S. and Norris, J. R.: Meteorological bias in satellite estimates of aerosol-cloud relationships, Geophys. Res. Lett., 34, L16824, doi:10.1029/2007GL029952, 2007.

Meloni, D., di Sarra, A., di Iorio, T., and Fiocco, G.: Influence of the vertical profile of Saharan dust on the visible direct radiative forcing, J. Quant. Spectrosc. Ra., 93, 397-413, 2005.

Merrill, J., Uematsu, M., and Bleck, R.: Meteorological analysis of long-range transport of mineral aerosols over the North Pacific, J. Geophys. Res.-Atmos., 94, 8584-8598, 1989.

Meyer, K., Platnick, S., Oreopoulos, L., and Lee, D.: Estimating the direct radiative effect of absorbing aerosols overlying marine boundary layer clouds in the southeast Atlantic using MODIS and CALIOP, J. Geophys. Res.-Atmos., 118, 4801-4815, 2013.

Min, M. and Zhang, Z.: On the influence of cloud fraction diurnal cycle and sub-grid cloud optical thickness variability on all-sky direct aerosol radiative forcing, J. Quant. Spectrosc. Ra., 142, 25-36, 2014.

Myhre, G.: Consistency between satellite-derived and modeled estimates of the direct aerosol effect, Science, 325, 187-190, 2009.

Myhre, G., Shindell, D., Bréon, F.-M., Collins, W., Fuglestvedt, J., Huang, J., Koch, D., Lamarque, J.-F., Lee, D., Mendoza, B., Nakajima, T., Robock, A., Stephens, G., Takemura, T., and Zhang, H.: Anthropogenic and Natural Radiative Forcing, in: Climate Change 2013: The Physical Science Basis. Contribution of Working Group I to the Fifth Assessment Report of the Intergovernmental Panel on Climate Change, IPCC report, V, Cambridge University Press, Cambridge, UK and New York, NY, USA, 2013a.

Myhre, G., Samset, B. H., Schulz, M., Balkanski, Y., Bauer, S., Berntsen, T. K., Bian, H., Bellouin, N., Chin, M., Diehl, T., Easter, R. C., Feichter, J., Ghan, S. J., Hauglustaine, D., Iversen, T., Kinne, S., Kirkevåg, A., Lamarque, J.-F., Lin, G., Liu, X., Lund, M. T., Luo, G., Ma, X., van Noije, T., Penner, J. E., Rasch, P. J., Ruiz, A., Seland, Ø., Skeie, R. B., Stier, P., Takemura, T., Tsigaridis, K., Wang, P., Wang, Z., Xu, L., Yu, H., Yu, F., Yoon, J.-H., Zhang, K., Zhang, H., and Zhou, C.: Radiative forcing of the direct aerosol effect from AeroCom Phase II simulations, Atmos. Chem. Phys., 13, 1853-1877, doi:10.5194/acp-13-18532013, 2013b.

Omar, A. H., Winker, D. M., Vaughan, M. A., Hu, Y., Trepte, C. R., Ferrare, R. A., Lee, K.-P., Hostetler, C. A., Kittaka, C., Rogers, R. R., Kuehn, R. E., and Liu, Z.: The CALIPSO Automated Aerosol Classification and Lidar Ratio Selection Algorithm, J. Atmos. Ocean. Tech., 26, 1994-2014, 2009.

Rogers, R. R., Vaughan, M. A., Hostetler, C. A., Burton, S. P., Ferrare, R. A., Young, S. A., Hair, J. W., Obland, M. D., Harper, D. B., Cook, A. L., and Winker, D. M.: Looking through the haze: evaluating the CALIPSO level 2 aerosol optical depth using airborne high spectral resolution lidar data, Atmos. Meas. Tech., 7, 4317-4340, doi:10.5194/amt-7-4317-2014, 2014. 
Rozendaal, M. A., Leovy, C. B., and Klein, S. A.: An Observational Study of Diurnal Variations of Marine Stratiform Cloud, J. Climate, 8, 1795-1809, 1995.

Su, W., Loeb, N. G., Schuster, G. L., Chin, M., and Rose, F. G.: Global all-sky shortwave direct radiative forcing of anthropogenic aerosols from combined satellite observations and GOCART simulations, J. Geophys. Res.-Atmos., 118, 655-669, 2013.

Torres, O., Jethva, H., and Bhartia, P. K.: Retrieval of Aerosol Optical Depth above Clouds from OMI Observations: Sensitivity Analysis and Case Studies, J. Atmos. Sci., 69, 1037-1053, 2012.

VanCuren, R. A.: Asian aerosols in North America: Extracting the chemical composition and mass concentration of the Asian continental aerosol plume from long-term aerosol records in the western United States, J. Geophys. Res.-Atmos., 108, 4623, doi:10.1029/2003JD003459, 2003.

Vaughan, M. A., Powell, K. A., Winker, D. M., Hostetler, C. A., Kuehn, R. E., Hunt, W. H., Getzewich, B. J., Young, S. A., Liu, Z., and McGill, M. J.: Fully automated detection of cloud and aerosol layers in the calipso lidar measurements, J. Atmos. Ocean. Tech., 26, 2034-2050, 2009.

Waquet, F., Riedi, J., Labonnote, L. C., Goloub, P., Cairns, B., Deuzé, J. L., and Tanré, D.: Aerosol Remote Sensing over Clouds Using A-Train Observations, J. Atmos. Sci., 66, 2468-2480, 2009.
Waquet, F., Peers, F., Ducos, F., Goloub, P., Platnick, S., Riedi, J., Tanré, D., and Thieuleux, F.: Global analysis of aerosol properties above clouds, Geophys. Res. Lett., 40, 5809-5814, 2013.

Wilcox, E. M.: Stratocumulus cloud thickening beneath layers of absorbing smoke aerosol, Atmos. Chem. Phys., 10, 1176911777, doi:10.5194/acp-10-11769-2010, 2010.

Winker, D. M., Vaughan, M. A., Omar, A., Hu, Y., Powell, K. A., Liu, Z., Hunt, W. H., and Young, S. A.: Overview of the CALIPSO Mission and CALIOP Data Processing Algorithms, J. Atmos. Ocean. Tech., 26, 2310-2323, 2009.

Winker, D. M., Tackett, J. L., Getzewich, B. J., Liu, Z., Vaughan, M. A., and Rogers, R. R.: The global 3-D distribution of tropospheric aerosols as characterized by CALIOP, Atmos. Chem. Phys., 13, 3345-3361, doi:10.5194/acp-13-3345-2013, 2013.

Wood, R., Bretherton, C. S., and Hartmann, D. L.: Diurnal cycle of liquid water path over the subtropical and tropical oceans, Geophys. Res. Lett., 29, 7-1-7-4, 2002.

Young, S. A. and Vaughan, M. A.: The Retrieval of Profiles of Particulate Extinction from Cloud-Aerosol Lidar Infrared Pathfinder Satellite Observations (CALIPSO) Data: Algorithm Description, J. Atmos. Ocean. Tech., 26, 1105-1119, 2009. 